\title{
Transformation of the Father's Role in the Domestic Parenting System
}

\author{
Raisa Ekhaeva ${ }^{1,}{ }^{*}$ Nasrudi Yarychev ${ }^{2}$ \\ ${ }^{1,2}$ Chechen State University named after A.A. Kadyrova, Grozny, Russia \\ *Email: raisa.exaeva.65@mail.ru
}

\begin{abstract}
The father's role in the upbringing of children differs among different peoples and is transformed depending on the epoch: its social and economic structure. A historical digression allows us to understand the trends of such a transformation, based on which we try to understand the present better and predict future periods. It is possible to understand the place and role of the father in seed education based on the analysis of folklore (folk tales, songs, proverbs, sayings, traditions), religious rituals and holidays, state documents, scientific and literary sources. Our article is devoted to analysing the father's role in the upbringing of children in our country. We believe that in the domestic education system, such aspects as the need of children for authority; children's need for a model of a man's family behaviour also remain in demand.
\end{abstract}

Keywords: Education, Folk art, Training, The role of father and mother, Family, Society, Self-realisation.

\section{INTRODUCTION}

The ancient period of the history of Russia was of interest to many researchers (D.S. Likhachev [1], N.M. Karamzin [2], S.M. Solovyov [3], etc.), who noted that in Russia, the image of the father did not receive such a vivid expression as the image of the mother. The man was more personified as a defender of the Fatherland, family and his household, who controls what is happening in the family and makes sole decisions on most issues; this can be seen in the first books "The Life of Theodosius of the Caves" and "The Teachings of Vladimir Monomakh".

This trend is probably related to the religious idea of the roles of women and men. N.S. Berdyaev noted that Russian Orthodoxy tends to the feminine principle, in every way supporting and glorifying the role of the mother in human life [4]. Iconographic images confirm this fact in Orthodoxy (let us recall the variation of icons of the Mother of God). And Western culture is more focused on male iconography, i.e., the masculine principle.

The analysis of folk art makes it possible to talk about the mother's primary role in the upbringing of children (for example, "without a father, half an orphan, and without a mother, the whole orphan").

For the first time, the father's role in the child's upbringing was noted in the 16th century in the famous "Domostroy" - a set of family rules. The father was obliged to provide the child financially, to educate and educate him. At the same time, the main methods of education should have been strictness, various restrictions and punishments for disobedience. Emotional restraint and severity were welcomed [5].

In the 17th century, Russian pedagogy was significantly influenced by the works of Western European thinkers. Therefore, for the first time, the value of fatherhood was noted as "comprehension of the life meaning" by S. Polotsky [6]. This circumstance is precious since Simeon Polotsky was the teacher of the Russian tsars.

In the next two centuries in Russia, the children's upbringing was attributed to the state, and the parents' role, including the father, was reduced only to childbearing [7].

After the abolition of serfdom and before the Great October Socialist Revolution, pedagogical thought in 
Russia intensified on the importance of the family in the upbringing of children. Still, the primary role in this process was assigned to mothers. The fathers' role in theoretical issues was not considered since, as per P.F. Kapterev, men work hard and stay out of the family for a long time, so they cannot engage in education [8].

For decades of Soviet power, mothers assumed all responsibility for the upbringing of children. The father fulfilled his traditional role of protector and warrior. And it was only in 1993 that the new Constitution, for the first time, stipulated that the father and mother have not only equal rights in the family but also equal responsibilities for the upbringing of children [9].

In modern psychological and pedagogical science, the problem of fatherhood is widely represented in the works of leading researchers of family psychology and family education: I.S. Kon [10], V.N. Druzhinin [11], Yu.V. Borisenko [12], R.V. Ovcharova [13], et al.

\section{RESEARCH METHODOLOGY}

The study was conducted using scientifically reliable survey methods. Three surveys were conducted during the study. The first survey was conducted among children of preschool educational institutions. Primary school teachers and students took part in the second survey. The parents of the children took part in the third survey. The survey was conducted in an anonymous form, which indicates that objective, reliable results were obtained.

\section{RESEARCH RESULTS}

To understand the father's role in the modern family, we surveyed 327 students of Stavropol universities. The results are as follows:

- students noted family as values in their lives $(92.7 \%)$;

- most students consider the mother to be the main one in the family. To a direct question about the dominant role in the family, $38.6 \%$ noted the mother, 29.6 - the father, $31.8 \%$ of students noted equality. At the same time, in the indirect question "List your family members" $-76.3 \%$ started the transfer with mother;

- most students understand the family as the totality of all close relatives, i.e. the extended family type is valuable. In the survey, when listing family members, brothers and sisters, grandfathers and grandmothers were indicated $-81.4 \%$

- students see the father's role in the upbringing of children at a low level; in particular, only $33.1 \%$ of respondents named their father's example as a model of the "ideal father". At the same time, $44.1 \%$ consider those who satisfy their emerging household or financial needs to be "ideal" fathers. This leads to sad reflections.
Indeed, there is a lot of talk about equality in the family at the moment. This concerns both the decisions taken and the economic support of the family, responsibility for the upbringing of children. However, such equality remains declarative mainly. We received this statement based on several surveys of children:

The first survey we conducted was in the senior and preparatory kindergarten group. 56 pupils participated in it. The results are as follows:

- to the question "who plays with you most often at home" $45.3 \%$ of children named brothers, sisters and neighbourhood guys; $37.2 \%$ - pointed to mothers, only $17.5 \%$ - fathers;

- to the question "who brings you and takes you out of kindergarten" the following proportion was received $67.4 \%$ - mothers, $32.6 \%$ - fathers;

- 76.7\% of kindergarten students attend additional sections and clubs, of which $82.2 \%$ noted that their mothers take them there.

In the second survey we conducted with primary school teachers (37 people), we were interested in fathers' presence at parent meetings and the number of their requests for advice and explanations. It turned out that no more than $10 \%$ of fathers are present at parent meetings, and in some classes, only mothers are present at parent meetings $100 \%$. Teachers noted the request for advice or questions from fathers as 5-8\% of the class students.

We conducted the third survey with the fathers of students in grades 1-4 of 2 schools. The questionnaire was transmitted through the students, so we cannot guarantee the results' accuracy. But in general, the situation turned out to be the following. Men believe that their wives (female mothers) will find a common language with female teachers faster and better. And if there is a male teacher, they will take over the resolution of complex issues.

But the question "why don't they play with their children $-67.3 \%$ answered that they don't know games that would be interesting to their children; $30.6 \%$ responded that they don't have time for this, and $2.1 \%$ answered that they are not interested. They pay for all the sections and clubs, let them play with them there.

\section{RESULTS DISCUSSION}

As a result of the study, it can be concluded that the passive father's role in the family is associated with the existing socio-economic conditions in our country. The social stratification of society and the increased responsibility of fathers for the family's financial wellbeing have severe psychological pressure on men. And in the case of financial instability or a man's lack of a wellpaid job, it makes it impossible to consider him as a positive, exemplary example of a father. Thus, business 
success often becomes synonymous with the concept of a "good father."

\section{CONCLUSIONS}

However, there are examples of excellent attention from a man side to his wife and children, with an average level of wealth. In this case, we can talk about the selfrealisation of a man in the family and caring for others. Although in Orthodox traditions, this role should belong to women.

In this case, the pedagogical community faces the most important tasks - to promote a rethinking of family relationships, promote the father's status and role in the upbringing of children, and teach men games with children of different ages.

As can be seen from the study, the father's role in the modern family is quite peculiar and requires close attention from specialists of various levels, considering the emerging transformations in contemporary society, which entail the social distancing of children from their parents. Therefore, it is necessary to ensure the interaction of fathers and children on the modern understanding of the meaning of life.

\section{REFERENCES}

[1] D.S. Likhachev, Letters about the good and the beautiful, SPb.: Publishing house "LOGOS", 2006, $311 \mathrm{p}$.

[2] N.M. Karamzin, Pleasant views, hopes and desires of the present time // N.M. Karamzin, Fav. op.: in 2 volumes, M.; L. 2 (1964) 268-277.

[3] V.S. Soloviev, Readings about God-manhood. Spiritual foundations of life. Justifying Good, Minsk: Harvest, 1999.

[4] N.A. Berdyaev, About the appointment of a person. An experience of paradoxical ethics, M. Armita, 2019, 460 p.

[5] E.I. Zeiliger-Rubinstein, Essays on the history of education and pedagogical thought. L.: publishing house of Leningrad State University, 1978, 108 p.

[6] M.A., Robinson, L.I. Sazonova, Notes to the biography and work of Simeon Polotsky // Russian literature 4 (1988) 134-141.

[7] V.V. Zenkovsky, On religious education in the family // Questions of Orthodox pedagogy, M. 1 (1992) 51-59.

[8] P.F. Kapterev, Family education tasks. Favourites, M.: Karapuz, 2005, 192 p.
[9] O.A. Shavaeva, Family values as an object of social and philosophical analysis // Scientific journal of KubSAU 96 (2014) 1-12.

[10] I.S. Kon, Ethnography of parenthood [Etnografiya roditel'stva], M., 2000.

[11] V.N. Druzhinin, Psychology of the family [Psihologiya sem'i] / V.N. Druzhinin. Yekaterinburg, 2000, 208 p.

[12] Yu.V. Borisenko, Psychology of fatherhood [Psihologiya otcovstva] / Yu.V. Borisenko. Moscow-Obninsk: "IGSOTSIN" [«IGSOCIN»], 2007, 220 p.

[13] R.V. Ovcharova, Psychology of parenthood: a manual for university students [Psihologiya roditel'stva: ucheb. posobie dlya stud. vyssh. Ucheb, zavedenij] / R.V. Ovcharova, Moscow: Publishing Centre "Academy" [Moskva: Izdatel'skij centr «Akademiya»], 2005, 368 p. 